\title{
Potential Application of Probiotics in the Prevention and Treatment of Inflammatory Bowel Diseases
}

\author{
Silvina del Carmen, ${ }^{1}$ Alejandra de Moreno de LeBlanc, ${ }^{1}$ Anderson Miyoshi, ${ }^{2}$ \\ Clarissa Santos Rocha, ${ }^{2}$ Vasco Azevedo, ${ }^{2}$ and Jean Guy LeBlanc ${ }^{1}$ \\ ${ }^{1}$ Centro de Referencia para Lactobacilos (CERELA-CONICET), Chacabuco 145, San Miguel de Tucumán T4000ILC, Argentina \\ ${ }^{2}$ Institute of Biological Sciences, Federal University of Minas Gerais (UFMG-ICB), Belo Horizonte, MG, CEP 31270-901, Brazil
}

Correspondence should be addressed to Vasco Azevedo, vasco@mono.icb.ufmg.br

Received 13 August 2010; Accepted 25 November 2010

Academic Editor: Gyula Mozsik

Copyright (c) 2011 Silvina del Carmen et al. This is an open access article distributed under the Creative Commons Attribution License, which permits unrestricted use, distribution, and reproduction in any medium, provided the original work is properly cited.

Lactic acid bacteria (LAB) represent a heterogeneous group of microorganisms that are naturally present in many foods and possess a wide range of therapeutic properties. The aim of this paper is to present an overview of the current expanding knowledge of the mechanisms by which $\mathrm{LAB}$ and other probiotic microorganisms participate in the prevention and treatment of inflammatory bowel diseases. These include changes in the gut microbiota, stimulation of the host immune responses, and reduction of the oxidative stress due to their antioxidant properties. A brief overview of the uses of genetically engineered LAB that produce either antioxidant enzymes (such as catalase and superoxide dismutase) or anti-inflammatory cytokines (such as IL-10) will also be discussed. This paper will show that probiotics should be considered in treatment protocols of IBD since they provide many beneficial effects and can enhance the effectiveness of traditional used medicines.

\section{Introduction}

Inflammatory bowel disease (IBD) is a term applied to a group of bowel disorders in which inflammation is a major feature, but where there is no proven evidence that infection is the causative agent. Rare forms of inflammatory bowel disease exist but the two main entities are ulcerative colitis (UC) [1] and Crohn's disease (CD) [2]. There is evidence that these do not represent discrete conditions but rather are the same disease with shared aetiological factors [3]. The different clinical manifestations may reflect the particular tissue involved or the affected individual's immunological and constitutional endowment.

Despite many years of study, the exact etiology and pathogenesis of these disorders remain unclear. The use of experimental animal models have provided insights into the complex, multifactorial processes, and mechanisms that can result in chronic intestinal inflammation [4]. These models have a number of advantages in that the environmental conditions and genetics can be either controlled or defined.
The use of animal models has proven useful in the study of IBD and is a necessary step in testing new drugs before launching clinical trials. Animal models of IBD can be classified into five principal categories based on the methods of induction: (i) gene knockout (KO) models, (ii) transgenic models, (iii) spontaneous colitis models, (iv) inducible colitis models, and (v) adoptive transfer models [5]. Knowledge gained from these experimental models has already resulted in the development of new hypothesis and therapies that are being tested in patients with different IBD.

The aim of this paper is to present an overview of the current expanding knowledge of the mechanisms by which lactic acid bacteria (LAB) and other probiotic microorganisms participate in the prevention and treatment of IBD. Table 1 gives a brief overview of some examples of native bacterial strains with proven antiinflammatory properties classified by their mechanisms of action. These include changes in the gut microbiota, stimulation of the host immune responses, and reduction of the oxidative stress due to their antioxidant properties. In the following sections, these mechanisms will be discussed in more detail. 
TABLE 1: Examples of probiotics with proven antiinflammatory properties classified by their mechanisms of action.

\begin{tabular}{|c|c|c|c|}
\hline Mechanism & Strain* & Demonstrated effect & Reference \\
\hline \multirow{9}{*}{ Immune } & B. longum & $\begin{array}{l}\text { Improvement of clinical appearance of chronic } \\
\text { inflammation in patients, decreases in TNF- } \alpha \text { and IL- } 1 \alpha\end{array}$ & {$[6]$} \\
\hline & BIFICO (3 bifidobacteria species) & $\begin{array}{l}\text { Prevention of flare-ups of chronic ulcerative colitis, } \\
\text { inactivation of NF- } \kappa \mathrm{B} \text {, decreased expressions of TNF- } \alpha \\
\text { and IL- } 1 \beta \text { and elevated expression of IL-10 }\end{array}$ & [7] \\
\hline & L. salivarius ssp. salivarius CECT5713 & $\begin{array}{l}\text { Recovery of inflamed tissue in TNBS model of rat } \\
\text { colitis, increase in TNF- } \alpha \text { and iNOS (inducible NO } \\
\text { synthase) expression }\end{array}$ & {$[8]$} \\
\hline & L. fermentum, L.reuteri & $\begin{array}{l}\text { Improvement of histology in a TNBS model of rat } \\
\text { colitis, decreased levels of TNF- } \alpha \text { and i-NOS expression }\end{array}$ & {$[9]$} \\
\hline & L. casei Shirota & $\begin{array}{l}\text { Improvement in murine chronic inflammatory bowel } \\
\text { disease, downregulation of proinflammatory cytokines } \\
\text { such as IL- } 6 \text { and IFN- } \gamma\end{array}$ & {$[10]$} \\
\hline & L. casei $\mathrm{DN}-114001$ & $\begin{array}{l}\text { Reduction in numbers of activated T lymphocytes in } \\
\text { the lamina propria of Crohn's disease mucosa, decrease } \\
\text { of IL- } 6 \text { and TNF- } \alpha\end{array}$ & {$[11]$} \\
\hline & L. plantarum 299v & $\begin{array}{l}\text { Decreased IL-12, IFN- } \gamma \text { and IG2a at the mucosal level } \\
\text { of specific pathogen free IL-10 KO mice. Decreased } \\
\text { mesenteric lymph node IL-12 and IFN- } \gamma \text { production as } \\
\text { well as histologic colitis scores in the pretreatment of } \\
\text { GF mice that were exposed to normal flora. }\end{array}$ & {$[12]$} \\
\hline & L. rhamnosus GG & $\begin{array}{l}\text { Alleviating intestinal inflammation, decrease TNF- } \alpha \text {. } \\
\text { Specific inhibition of macrophages TNF- } \alpha \text { production } \\
\text { by a contact independent mechanism }\end{array}$ & {$[13,14]$} \\
\hline & L. salivarus UCC118 & $\begin{array}{l}\text { Reduced production of proinflammatory cytokines in } \\
\text { IL-10 KO mice injected subcutaneously with the } \\
\text { probiotic strain }\end{array}$ & {$[15]$} \\
\hline \multirow{7}{*}{$\begin{array}{l}\text { Microbiota } \\
\text { alteration }\end{array}$} & L. salivarus UCC118 & $\begin{array}{l}\text { Reduction of C.perfringes, coliforms and enterococcus } \\
\text { levels in IL-10 KO mice }\end{array}$ & {$[16]$} \\
\hline & & $\begin{array}{l}\text { Production of a peptide that inhibits a broad range of } \\
\text { pathogens such as Bacillus, Staphylococcus, Enterococcus, } \\
\text { Listeria and Salmonella species }\end{array}$ & {$[17]$} \\
\hline & L reuteri & $\begin{array}{l}\text { Decreased concentration of colonic Lactobacillus } \\
\text { species and increased concentration of mucosal } \\
\text { adherent bacteria associated with colitis attenuation }\end{array}$ & {$[18]$} \\
\hline & & $\begin{array}{l}\text { Delayed relapse into pouchitis after surgical resection in } \\
\text { human patients }\end{array}$ & {$[19]$} \\
\hline & VSL\#3 & $\begin{array}{l}\text { Decreased luminal } \mathrm{pH} \text { in patients with } \mathrm{UC} \text { that } \\
\text { antagonizes pathogenic bacteria }\end{array}$ & {$[20]$} \\
\hline & & $\begin{array}{l}\text { Reduced counts of bifidobacteria and lactobacilli in } \\
\text { pouchitis }\end{array}$ & {$[21]$} \\
\hline & & Delayed relapse into pouchitis after surgical resection & {$[22]$} \\
\hline \multirow{4}{*}{ Unknown } & $\begin{array}{l}\text { L. rhamnosus } G G, L \text {. rhamnosus } L c 705, P \text {. } \\
\text { freudenreichii ssp. shermanii JS and B. breve } \\
\text { Bb99 }\end{array}$ & Alleviating irritable bowel syndrome symptoms & {$[23]$} \\
\hline & B. and L. plantarum & $\begin{array}{l}\text { Improvement of the disease activity index in an } \\
\text { induced rat colitis model }\end{array}$ & {$[24]$} \\
\hline & L. rhamnosus GG & $\begin{array}{l}\text { Improvement in the clinical status in children with } \\
\text { mildly to moderately active stable Crohn's disease }\end{array}$ & {$[25]$} \\
\hline & L. casei Shirota & $\begin{array}{l}\text { Improvement in the clinical condition of murin DSS } \\
\text { model of ulcerative colitis }\end{array}$ & {$[26]$} \\
\hline
\end{tabular}




\section{The Influence of Gut Microbiota in IBD}

Most of the models in which animals develop spontaneous or chemically induced colitis are influenced by the microbiota present in the intestinal lumen. This fact is supported by the reduction or absence of intestinal inflammation in trinitrobenzene sulfonic acid (TNBS) or dextran sulfate sodium (DSS) models of colitis using antibiotic-treated and germ-free animals [27-29]. In addition, many studies have shown that not all bacterial species have equal activities in promoting or reducing intestinal inflammation.

The TNBS model is associated with the absence of Lactobacillus and an increase in the number of other aerobic isolates such as Escherichia (E.) coli and Staphylococcus spp. [30]. Similarly, decreased levels of faecal lactobacilli and bifidobacteria have also been reported in Crohn's disease [31].

In humans, it was shown that IBD patients have a completely different intestinal microbiota compared to healthy individuals [32-34]. The predominance of potentially harmful bacteria as well as a decrease of commensal bacterial species such as Lactobacillus and Bifidobacterium has been identified in the intestinal microbiota of patients with IBD [35-37]. Manipulating the abnormal enteric microbiota to decrease the more pathogenic species and enhancing the concentration and metabolic activity of the beneficial species has potential as an alternative therapy for IBD [38]; administration of certain microorganisms can exert a beneficial effect on the pathogenic/beneficial balance of the microbiota [39].

\section{Use of Probiotics in the Treatment of Colitis}

$\mathrm{LAB}$ represent a heterogeneous group of microorganisms that are naturally present in many foods. Several studies have shown that LAB possess therapeutic properties since they are able to prevent the development of some diseases as shown mostly using animal models for cancer, infections, and gastrointestinal disorders such as IBD [40]. Because of the numerous beneficial properties that have been attributed to $\mathrm{LAB}$, these are the most commonly used probiotic microorganisms that can be defined as "live microorganisms which when administered in adequate amounts confer a health benefit on the host" [41]. Probiotic microorganisms, including strains of lactobacilli, bifidobacteria, and Saccharomyces, can potentiate the effect of conventional treatments for experimental colitis or other IBD in humans [22, 42, 43]. Table 2 describes some examples of human clinical trials where probiotics were shown to be effective in the prevention or treatment of different IBD.

Probiotic bacteria can counteract inflammatory processes by stabilizing the gut microbial environment and the permeability of the intestinal barrier and by enhancing the degradation of enteral antigens and altering their immunogenicity [53]. It was reported that Lactobacillus ( $L$.) reuteri could be used to prevent colitis in IL-10 KO mice by increasing the number of $\mathrm{LAB}$ in the gastrointestinal tract [18]. Neonatal mice presented a decreased concentration of colonic Lactobacillus species and an increased concentration of mucosal adherent bacteria. Oral administration of the prebiotic lactulose increased the levels of Lactobacillus species and rectal swabbing with $L$. reuteri restored Lactobacillus levels to normal and reduced the number of adherent bacteria within the colon. These effects were associated with the attenuation of colitis [18].

In a placebo-controlled trial, orally administered $L$. salivarius UCC118 reduced prevalence of colon cancer and mucosal inflammatory activity in IL-10 KO mice by modifying the intestinal microbiota in these animals: Clostridium (C.) perfringens, coliforms, and enterococcus levels were significantly reduced in the probiotic fed group [16].

Gut microbiota can antagonize pathogenic bacteria by conferring a physiologically restrictive environment inhibiting bacterial adherence and translocation, or producing antibacterial substances and defensins. Probiotic bacteria also decrease luminal $\mathrm{pH}$, as has been demonstrated in patients with UC following ingestion of the probiotic preparation VSL\#3, a mixture of 4 lactobacilli strains ( $L$. plantarum, $L$. casei, $L$. acidophilus, and $L$. delbrueckii ssp. bulgaricus), 3 bifidobacteria strains (Bifidobacterium (B.) infantis, B. breve, and B. longum), and 1 strain of Streptococcus salivarius ssp. thermophilus [20].

Another mechanism by which probiotics can exert a positive effect by inhibiting pathogenic microorganisms is by producing antimicrobial substances such as bacteriocins. Several bacteriocins produced by different Lactobacillus species have been described [54]. The inhibitory activity of these bacteriocins varies; for example, the probiotic $L$. salivarius UCC118 produces a peptide that inhibits a broad range of pathogens such as Bacillus, Staphylococcus, Enterococcus, Listeria, and Salmonella species [17]. Lacticin 3147, a broad-spectrum bacteriocin produced by a Lactococcus $(L c$.) lactis strain, inhibits a range of genetically distinct $C$. difficile isolated from healthy subjects, patients with IBD and from different origins [55].

The Symbiotic Instant Mixture (SIM) containing the prebiotic compound inulin, and a combination of probiotic microorganisms (L. acidophilus La-5 and B. lactis Bb-12) significantly reduced inflammation in transgenic rats that produce human HLA-B27- $\beta 2$-microglobulin. The effect was enhanced by combination with metronidazole, suggesting a synergistic effect of the combination of antibiotics and probiotics in the treatment of experimental colitis [56].

In a double-blind randomized study, the efficacy of VSL\#3 combined with antibiotic treatment on the postoperative recurrence of $\mathrm{CD}$ was compared to the treatment with mesalazine alone. Combination of antibiotic and probiotic treatment was more efficient in prophylaxis of postoperative recurrence of Crohn's disease [57].

The impetus for probiotic experimentation in pouchitis (another type of IBD) has arisen from literature showing disturbances in the intestinal microbiota. Pouchitis has been associated with reduced counts of bifidobacteria and lactobacilli [21]. It was shown that the VSL\#3 probiotic mixture was efficient in maintaining the remission in patients with chronic pouchitis [58]. 
TABLE 2: Examples of human clinical trials (randomized controlled trials) that have demonstrated that probiotics improve inflammatory bowel diseases including Crohn's Disease (CD), Irritable Bowel Syndrome (IBS), Pouchitis (PCH) and Ulcerative Colitis (UC).

\begin{tabular}{|c|c|c|c|}
\hline Disease & Results & Probiotic & Reference \\
\hline $\mathrm{CD}$ & $\begin{array}{l}\text { Relapse in } 6 \% \text { of patients supplemented with probiotic } \\
\text { strain versus } 38 \% \text { with conventional treatment only }\end{array}$ & S. boulardii & {$[44]$} \\
\hline CD & $\begin{array}{l}\text { Median pediatric CD activity index scores at } 4 \text { weeks } \\
\text { were } 73 \% \text { lower than baseline and intestinal } \\
\text { permeability improved in an almost parallel fashion. } \\
\text { The number of specific antibody secreting cells in the } \\
\text { IgA class to } \beta \text {-lactoglobulin increased significantly } \\
\text { from } 0.2(0.04-1.3) \text { to } 1.4(0.3-6.0) / 106 \text { cells and to } \\
\text { casein from } 0.3(0.1-1.4) \text { to } 1.0(0.2-4.8) / 106 \text { cells. }\end{array}$ & Lactobacillus GG & {$[25,45]$} \\
\hline IBS & $\begin{array}{l}\text { Alleviation of IBS symptoms and normalization of the } \\
\text { ratio of an antiinflammatory to a proinflammatory } \\
\text { cytokines in patients receiving probiotic strain versus } \\
\text { placebo group }\end{array}$ & B. infantis 35624 & {$[46]$} \\
\hline IBS & $\begin{array}{l}\text { Relapse in } 20 \% \text { of patients in probiotic group versus } \\
93 \% \text { in the placebo group. The probiotic impeded the } \\
\text { activation of NF- } \kappa \text { B, decreased the expressions of } \\
\text { TNF- } \alpha \text { and IL- } 1 \beta \text { and increased the expression of IL- } 10\end{array}$ & BIFICO ( 3 bifidobacteria species) & {$[7]$} \\
\hline IBS & $\begin{array}{l}\text { The total symptom score (abdominal pain }+ \text { distension } \\
+ \text { flatulence }+ \text { borborygmi) was reduced } 42 \% \text { in the } \\
\text { probiotic group compared with } 6 \% \text { in the placebo } \\
\text { group }\end{array}$ & $\begin{array}{l}\text { L.rhamnosus GG, L.rhamnosus Lc705, } P \text {. } \\
\text { freudenreichii spp shermanii JS, B. breve Bb99 }\end{array}$ & {$[23]$} \\
\hline IBS & $\begin{array}{l}\text { The probiotic + prebiotic treatment showed short-term } \\
\text { and long-term reductions in IBS symptoms }\end{array}$ & $\begin{array}{l}\text { Prescript-Assist (probiotic+prebiotic complex } \\
\text { containing } 29 \text { soil-based, pH-resistant } \\
\text { microflora) }\end{array}$ & {$[47]$} \\
\hline IBS & $\begin{array}{l}\text { The probiotic + prebiotic treatment was associated } \\
\text { with significant reductions in } 3 \text { subsyndromic factors of } \\
\text { IBS: general ill feelings/nausea, indigestion/flatulence, } \\
\text { and colitis }\end{array}$ & Prescript-Assost & {$[48]$} \\
\hline $\mathrm{PCH}$ & $\begin{array}{l}\text { The probiotic mixture was effective in maintaining } \\
\text { antibiotic introduced remission for at least a year in } \\
\text { patients with recurrent or refractory pouchitis }(85 \%) \\
\text { versus } 6 \% \text { in the placebo group }\end{array}$ & $\begin{array}{l}\text { VSL\#3 (probiotic preparation containing } 3 B . \text {, } \\
4 . L \text { and } 1 \text { St. strains) }\end{array}$ & [49] \\
\hline $\mathrm{PCH}$ & $\begin{array}{l}10 \% \text { of patients treated with probiotics had an episode } \\
\text { of acute pouchitis compared with } 40 \% \text { treated with } \\
\text { placebo. Treatment with probiotic improved } \\
\text { Inflammatory bowel disease Questionnaire score versus } \\
\text { placebo }\end{array}$ & VSL\#3 & {$[22]$} \\
\hline UC & $\begin{array}{l}\text { Sigmoidoscopy scores were reduced in probiotic group } \\
\text { compared with placebo. TNF- } \alpha \text { and IL- } 1 \alpha \text { were reduced } \\
\text { after treatment with probiotic }\end{array}$ & Symbiotic therapy (B. longum and Synergy 1) & {$[6]$} \\
\hline UC & $\begin{array}{l}\text { The probiotic treatment was just as effective as the } \\
\text { conventional treatment (mesalazine) in maintaining } \\
\text { remission }\end{array}$ & E. coli Nissle 1917 & {$[50]$} \\
\hline UC & $\begin{array}{l}\text { Probiotic supplementation improved remission } \\
\text { compared to conventional treatment (balsalazide) alone }\end{array}$ & VSL\#3 & {$[51]$} \\
\hline UC & Probiotic preparation maintains remission $(75 \%)$ & VSL\#3 & [20] \\
\hline UC & $\begin{array}{l}62 \% \text { of patients showed improvement of symptoms } \\
\text { and } 0 \% \text { showed relapse of intestinal disease while on } \\
\text { probiotics }\end{array}$ & VSL\#3 & [52] \\
\hline
\end{tabular}

\section{Immunomodulatory Properties of Probiotics}

Cytokines, mediators produced by immune cells, are involved in the regulation of activation, growth, and differentiation of immune cells and also in the inflammation and immune tolerance processes. Studies in IBD models have shown a deregulation of $\mathrm{T}$ cells due to the differentiation and activation of $\mathrm{T}$ cells by cytokines. A deletion or apoptosis of over- and autoreactive cells are affected by an imbalance between Treg/Th1, Th2, and Th17 in an active state, where 
TABLE 3: Examples of genetically modified (GM) bacterial strains with proven antiinflammatory properties classified by their mechanisms of action.

\begin{tabular}{|c|c|c|c|}
\hline Mechanism & Strain* & Proven effects & Reference \\
\hline \multirow[t]{4}{*}{ Immune } & L. plantarum NCIMB8826 $\Delta$ Dlt & $\begin{array}{l}\text { Reduction of secretion of proinflammatory cytokines } \\
\text { by peripheral blood mononuclear cells and monocytes } \\
\text { and increase in IL-10 production in a murine colitis } \\
\text { model }\end{array}$ & {$[116]$} \\
\hline & Lc. lactis IL-10 & $\begin{array}{l}\text { Reduction of colitis in mice treated with DSS and } \\
\text { prevention of the onset of colitis in IL-10 knockout } \\
\text { mice. }\end{array}$ & {$[101]$} \\
\hline & & $\begin{array}{l}\text { Attenuation of the severity of inflammation in CD } \\
\text { patients }\end{array}$ & {$[102]$} \\
\hline & & $\begin{array}{l}\text { Regulation of inflammatory cascades in an asthma } \\
\text { model }\end{array}$ & {$[103]$} \\
\hline \multirow{2}{*}{ CAT } & L. casei BL23 MnKat & $\begin{array}{l}\text { Reduction of cecal and colonic inflammatory scores in } \\
\text { a DSS-induced colitis model }\end{array}$ & {$[117]$} \\
\hline & & $\begin{array}{l}\text { Significat reduction of physiological damages in a } \\
\text { TNBS-induced colitis model }\end{array}$ & {$[121]$} \\
\hline \multirow{5}{*}{ SOD } & Lc. lactis + KatE & $\begin{array}{l}\text { Slight increase catalase activity in the intestines and } \\
\text { prevention of colon cancer or mice administered the } \\
\text { cancer inducing drug DMH }\end{array}$ & {$[118]$} \\
\hline & $\begin{array}{l}\text { Lc. lactis NZ9811 and L. plantarum } \\
\text { NCIMB8826+pNZ804 sodA }\end{array}$ & $\begin{array}{l}\text { Reduction in macroscopic damages in rats } \\
\text { administered TNBS to induce colitis }\end{array}$ & {$[119]$} \\
\hline & $\begin{array}{l}\text { L. gasseri } \mathrm{NC} 1501 \text { (sod } \\
\text { overexpression) }\end{array}$ & Reduction of inflammation in IL-10 deficient mice & {$[8]$} \\
\hline & L. casei $\mathrm{BL} 23+$ sodA & $\begin{array}{l}\text { Attenuation of colonic histological damage scores in a } \\
\text { DSS-induced colitis model. }\end{array}$ & {$[120]$} \\
\hline & & $\begin{array}{l}\text { Significat reduction of physiological damages in a } \\
\text { TNBS-induced colitis model. }\end{array}$ & $\begin{array}{l}\text { Unpublished } \\
\text { data }\end{array}$ \\
\hline
\end{tabular}

the lack of Treg cells or the excessive production of effector $\mathrm{T}$ cells participates in the development and exacerbation of IBD $[59,60]$.

There is a consensus that CD4+ lymphocytes with Th1 phenotype are dominant in the mucosa of patients with established CD. In contrast, the mucosa in patients with UC is dominated by CD4+ lymphocytes with a Th2 phenotype [61]. However, new immunological insights implicate Th17 cells in the pathogenesis of CD and the importance of the therapy for Th1 and Th17 cells as targets to treat this pathology [62]. Murine models of IBD demonstrated that CD4 T cell differentiation plays a pivotal role in determining the type of immune response generated in the gut and that distinct cytokine profiles characterize each CD4 T cell subset (Th1, Th2, Th17 and Tr) [63-65].

The elevated frequency of activated cytotoxic $\mathrm{T}$ cells and their important role in the pathogenesis of IBD has also been described [66]. These activated cytotoxic $\mathrm{T}$ cells exacerbate the inflammatory process through the release of proinflammatory cytokines and chemokines upon lysis of epithelial cells and the increased influx of luminal antigens at the site of epithelial erosions.

Considering that many beneficial effects of probiotics and fermented milks containing probiotic bacteria are related to their immunomodulatory capacities as well as their antiinflammatory activities [67], they are ideal candidates for the prevention and/or treatment of intestinal inflammations.
Probiotics can act regulating directly the gut immune system or indirectly inducing beneficial changes in the intestinal microbiota, as discussed previously in this paper. The tolerogenic effect of the gut microbiota may partially be mediated by the generation of regulatory $T$ cells. Certain LAB strains, normal inhabitants of the gut microbiota, have been shown to stimulate $\mathrm{T}$ helper cell populations which promote oral tolerance induction, preventing hypersensitivity and local inflammation $[68,69]$.

Specific pathogen free IL-10 KO mice that received $L$. plantarum $299 \mathrm{v}$ showed an attenuation of the previously established colonic inflammation and showed decreased IL12 , IFN- $\gamma$, and IgG2a at the mucosal level [12]. This probiotic bacterium was evaluated in the pretreatment of germ-free mice that were then exposed to normal flora. These mice significantly decreased IL-12 and IFN- $\gamma$ production in the mesenteric lymph node as well as significantly improved the histological colitis scores. These results demonstrate that the probiotic bacterium L. plantarum 299v can attenuate immune-mediated colitis and suggest a potential therapeutic role for this agent in clinical IBD [12].

Another study using BALB/c mice inoculated with TNBS showed that conventional yoghurt (produced using a pool of potentially probiotic strains of $L$. bulgaricus and $S$. thermophilus) administration exerted an antiinflammatory effect [70]. Yoghurt administration diminished the severity of inflammation mainly through IL-10, which was increased 
in the intestinal tissues, while IL-17 and IL-12 levels were decreased. These results show that yoghurt consumption can modulate the immune response, inducing downregulation of the inflammatory cytokines produced by the immune cells involved in the inflammatory process. The protective effect of yoghurt could also be mediated through beneficial changes in the intestinal microbiota favoring lactobacilli and bifidobacteria population [70].

It was recently shown that the oral route of administration may not be required for certain probiotics to exert their effects at the intestinal level. Reduced inflammatory scores and reduced production of proinflammatory cytokines have been observed in IL-10 KO mice that had been injected subcutaneously with L. salivarius UCC118 [15].

The immunomodulatory properties of LAB, through the repression of proinflammatory cytokines, could be one of the mechanisms by which these probiotic microorganisms are able to prevent and treat certain inflammatory diseases in the gastrointestinal tract. In this sense, it was shown that L. rhamnosus GG specifically inhibits macrophage TNF- $\alpha$ production by a contact-independent mechanism [13]. Other microbes can downregulate proinflammatory cytokines by inhibiting the epithelial cell NF- $\kappa \mathrm{B}$ pathway $[71,72]$.

Another human study has suggested that L. rhamnosus GG may improve gut barrier function and clinical status in children suffering from mildly to moderately active stable Crohn's disease [25]. Several studies have suggested the resistance of CD T cells to different apoptotic signals $[73,74]$. It was also demonstrated that IL- 6 and the complex formed with its soluble receptor mediates the resistance of $\mathrm{T}$ cells to apoptosis in CD contributing to the perpetuation of chronic intestinal inflammation [75]. In this sense, the modification of apoptosis and $\mathrm{T}$ cell regeneration by probiotics was evaluated by different strains. It was shown that the probiotic strain L. casei DN 114001 reduced the number of activated $\mathrm{T}$ lymphocytes in coculture with inflamed tissue of $\mathrm{CD}$ patients, diminishing the release of IL- 6 and TNF- $\alpha$ and lowering the expression of the antiapoptotic protein $\mathrm{Bcl}-2$ [11]. The probiotic Escherichia coli strain Nissle 1917 induces $\gamma / \delta$ T cell apoptosis mediated via TLR-2 by caspase- and Fas ligand-dependent pathways. It is known that $\gamma / \delta \mathrm{T}$ cells play an important role in the recognition of microbial antigens and the perpetuation of inflammatory processes and the regulation of this cell function contributes to explaining the biological function of this probiotic strain in inflammatory diseases.

Malin et al. reported that in pediatric $\mathrm{CD}$, consumption of $L$. rhamnosus GG was associated with increased gut IgA levels, which could promote the gut immunological barrier [45]. Patients that received a L. rhamnosus GG and fructooligosaccharide mixture showed a significant remission of pouchitis when administered as an adjunct to antibiotic therapy [76].

It was reported, in a randomized double-blind clinical trial with 120 UC patients, that oral administration of E. coli strain Nissle 1917 as a maintenance treatment of remission showed no difference in relapse rates compared with patients on mesalazine [77]. Relapse rates were $11.3 \%$ for the mesalazine-treated group and $16.0 \%$ for the E. coli group. Life table analysis showed a relapse free time of $64 \mathrm{~d}$ for mesalazine and $65 \mathrm{~d}$ for E. coli-treated patients. In a similar study, it was shown that the relapse rate in both groups was markedly higher than the investigators anticipated, $73 \%$ for the mesalazine group and $67 \%$ for the E. coli group [78]. These studies demonstrate that probiotics seem to have similar effects compared to the conventional treatments for UC.

The crucial role of IL-10 in the development of IBD has been demonstrated by experiments in IL-10-deficient mice. These animals develop a chronic bowel disease resembling $\mathrm{CD}$ in humans, which is in part caused by a loss of suppression of the mucosal immune response toward the normal intestinal microbiota [79]. Unfortunately, systemic IL-10 treatment of CD patients is not very effective in inducing clinical remission and is associated with considerable side effects, which are partly due to the fact that systemic IL-10 induces the proinflammatory cytokine IFN- $\gamma$ [80]. However, studies in experimental models suggest that topical treatment with IL-10 is effective to prevent certain inflammatory diseases. Recent studies have reported an accumulation of Foxp3 + CD4+ CD25+ cells in colon samples from patients with UC or CD and that subsets of IL-10-producing CD4+ $\mathrm{CD} 25+\mathrm{T}$ cells were present mainly within the intestinal lamina propria, suggesting compartmentalization of the Treg response at effector sites [81]. An orally administered mixture of B. longum Bar 33 and L. acidophilus Bar 13 prevented inflammation and mucosal ulcerations in a TNBSinduced colitis mouse model [82]. This protection was associated with an inhibition of the TNBS-induced increase of CD4+ population, upregulation of IL-10, downregulation of IL-12 and a different pattern of Foxp3+ CD4+ CD25+ cells in the intraepithelial and lamina propria lymphocytes [83].

The association of the Toll-like receptor (TLR) signaling deregulation and the pathogenesis of IBD infer the therapeutic potential of modulating TLRs signaling pathways $[84,85]$. Considering that probiotic bacteria and probiotic fermented products exert their effect mainly through the innate immune response stimulation [86-88], changes in the TLR expression can be associated to the beneficial effect of these microorganisms (and of products produced by or containing probiotics) in hosts with IBD.

The mechanisms of tolerance of the intestinal epithelium against bacterial ligands of the intestinal lumen are mediated by TLRs, which belong to a family of patternrecognizing receptors that detect conserved molecular products of microorganisms emerging as crucial elements in the activation of innate immunity as well as connectors between the innate and acquired immunity. TLR4 recognizes the LPS present in the membrane of Gram (-) bacteria such as Enterobacteriaceae family which together with other Gram (-) bacteria populations overgrow in an inflammatory process. In the colonic mucosa of IBD patient, a great concentration of Enterobacteriaceae and bacteroides were associated with the severity of the inflammation and TLR4 increase [89]. TLR4 is upregulated in both CD and UC. Studies have shown that inflammatory cytokines such as 
IFN- $\gamma$ and TNF- $\alpha$ increase expression of TLR4 and MD2 (myeloid differentiation protein 2 ), resulting in increased LPS responsiveness [90]. In this sense, the study of TLR showed that probiotic bacteria induced changes in the TLR expression in the immune and in the intestinal epithelial cells [91]. L. casei prevented the development of acute DSSinduced colitis in TLR4 KO mice by inhibiting myeloperoxidase activity and IL-12p40, and increasing TGF- $\beta$ and IL-10 mRNA. These effects suggest that the mechanism of action of L. casei depends largely on TLR4 status [92].

Isolated components of the probiotic cell may also have some therapeutic benefits. Bacterial DNA has been shown to have potent immunostimulatory effects. It was reported that bacterial DNA could attenuate colitis in a number of induced and spontaneous murine models [93]. Studies have shown that bacterial DNA derived from luminal bacteria contributes significantly to the perpetuation of chronic intestinal inflammation through TLR9. In TLR9deficient mice, the intestinal inflammation was significantly lower and the proinflammatory cytokine production was drastically reduced [94]. However, other intestinal epithelial cells recognize pathogenic bacterial DNA and respond by increasing surface localization and expression of TLR9 which led to the secretion of the proinflammatory cytokine IL8 [95]. Furthermore, several studies have shown that the presence of TLR9 is associated with the beneficial effect exerted by probiotics against IBD. It was reported that the inhibition of experimental colitis by probiotics was not observed in mice deficient in MyD88 or TLR9 [96]. In addition, these researchers also demonstrated that the attenuation of DSS colitis was caused by the DNA of VSL\#3 mixture through TLR9 signaling, and nonviable bacteria were equally effective in reducing inflammation in this model [97]. Heating E. coli strain Nissle 1917 and its isolated DNA were also administered in the DSS murine model and an antiinflammatory effect was demonstrated [98]. Interestingly, specific immunostimulatory DNA sequences have also been shown to attenuate the production of proinflammatory cytokines which are elevated in the mucosa of ulcerative colitis patients, suggesting that the animal model data may be applicable to human disease states [99].

The results of animal and human studies demonstrate that some probiotic strains can successfully modify the mucosal immune response to modulate the levels of specific activation molecules such as cytokines. By increasing IL-10 levels and in consequence decreasing inflammatory cytokines such as TNF- $\alpha$ and IFN- $\gamma$, some LAB can prevent the appearance of local inflammatory diseases and can successfully be used as an adjunct therapy with conventional treatments [40].

\section{LAB as Vehicles for Anti-IBD Compounds}

$\mathrm{LAB}$ are potential candidates to be used as vehicles for the production and delivery of heterologous proteins of vaccinal, medical, or technological interest and various delivery systems are now available for these probiotic microorganisms [100]. The use of LAB that produce antiinflammatory compounds (such as IL-10 and antioxidant enzymes) in the treatment of colitis and IBD will be discussed in the following sections.

5.1. IL-10-Producing Strains. Intragastric administration of a recombinant $L c$. lactis strain secreting murine IL-10 prevented onset of colitis in IL-10 KO mice and caused a $50 \%$ reduction of the inflammation in DSS-induced chronic colitis [101]. A placebo-uncontrolled trial using CD patients treated with a $L c$. lactis expressing mature human IL-10 showed that this genetically modified LAB was able to decrease the severity of this IBD [102]. The results of this phase I study confirmed that mucosal delivery of proteins is a feasible strategy in human beings holding promise for the safe application of live genetically modified Lc. lactis as a therapeutic tool in patients with chronic intestinal inflammation. The application of IL-10-producing LAB is not only limited to the treatment of IBD, recently it was shown that Lc. lactis expressing IL-10 could be used in the treatment of asthma because this cytokine plays a central role in the regulation of inflammatory cascades [103].

5.2. Antioxidant Enzyme-Producing Strains. IBD can frequently be associated with oxidative stress and epithelial damages. In IBD patients, oxidative stress occurs as a result of recurrent and abnormal inflammation. Several studies have established a correlation between the increase in reactive oxygen species (ROS) production and disease activity in inflamed biopsies of IBD patients [104-107]. Therefore, another mechanism by which LAB could prevent inflammation is through the expression of antioxidant enzymes that can degrade ROS or at least impair their formation.

ROS are normal byproducts of oxygen metabolism (such as superoxide ions, free radicals, and peroxides). These small molecules can be generated in aerobiosis by flavoproteins [108] and by phagocytes during inflammatory reactions [109]. At low quantities, ROS participate in cell signaling and regulatory pathways. However, when produced in large amounts, they act to eliminate infectious agents by causing significant damages to cell structures and macromolecular constituents such as DNA, RNA, proteins, and lipids [110]. When ROS concentration exceeds the capacity of cell defense systems, toxicity is triggered [111]. It has been shown that human tumor cells produce and excrete large amounts of $\mathrm{H}_{2} \mathrm{O}_{2}$ that might participate in tumor invasion and proliferation [112]. Thus, oxidative stress plays an important role in pathologies of the gastrointestinal tract of humans such as IBD as well as in certain types of cancers $[113,114]$.

The normal intestinal mucosa is equipped with a network of antioxidant enzymes that are able to neutralize ROS such as catalase (CAT), glutathione peroxidasa (GSH), glutathione reductase (GR), glutathione-s-transferase (GST), and superoxide dismutase (SOD). The activities of these enzymes are usually balanced to maintain a low and continual steadystate level of ROS; however, the levels of these enzymes are frequently depleted in IBD patients $[105,114]$. Probiotic LAB strains expressing high levels of antioxidant enzymes could increase these enzyme activities in specific locations of the gastrointestinal tract and could thus contribute to prevent oxidative epithelial damages, giving rise to potential 
applications for treatment of inflammatory diseases or postcancer drug treatments.

Since few microorganisms produce antioxidant enzymes at concentrations required toexert biological effects, genetic engineering strategies have been employed to produce antioxidant producing LAB. Recent reviews have shown the potential uses of such strains in the treatment of IBD using a variety of animal models $[40,115]$. Table 3 describes some examples of genetically engineered strains of $\mathrm{LAB}$ with proven antiinflammatory properties classified by their mechanisms of actions.

LAB have been used to locally deliver SOD directly to the intestines, an important breakthrough since oral administration of SOD is greatly limited by its short lifespan (5-10 $\mathrm{min})$ in the hostile conditions of the gastrointestinal tract. It was shown that genetically engineered $L$. plantarum and $L c$. lactis capable of producing and releasing SOD were found to exhibit anti-inflammatory effects in the TNBS colitis model [119]. Another experimental study demonstrated that $L$. gasseri producing manganese SOD had significant antiinflammatory activity reducing the severity of colitis in IL-10-deficient mice [8]. Recent data has shown that SOD producing $L$. case $i$ BL23 was able to significantly attenuate the TNBS-induced damages as shown by higher survival rates, decreased animal weight loss, lower bacterial translocation to the liver and the prevention of damage to the large intestines [121]. This is in agreement with previous results that have shown that the same SOD-expressing strain of L. casei was able to slightly attenuate the colonic histological damage score of a DSS-induced colitis model [122].

By definition, LAB, as a whole, are catalase negative microorganisms, thus genetic modifications are necessary in order for them to produce this important antioxidant enzyme. The food-grade $L c$. lactis is a potential vector to be used as a live vehicle to deliver heterologous proteins for vaccine and pharmaceutical purposes. Since Lc. lactis has no catalase, the B. subtilis heme catalase Kat E gene (ORF or open-reading frame) was introduced into this industrially important microorganism giving rise to a strain capable of producing active catalase that can provide efficient antioxidant activity [123]. Recently, the heterologous expression of nonheme catalase in bacteria relevant to dairy industries ( $L$. casei) has also been reported [124]. This latter strain offers the advantage that no exogenous heme has to be added to the culture medium in order to exert an efficient catalase activity. We have previously shown that the catalase-producing $L c$. lactis strain was able to prevent tumor appearance in the colon [118]. In another study, we have shown that a catalase producing strain of $L$. casei BL23 significantly decreased the physiological damages caused by the TNBS administration [121]. This result is similar to those obtained previously where it was shown that both the native strain of L. casei BL23 and its catalase producing derivative presented a significant reduction of caecal and colonic inflammatory scores [117].

\section{Conclusions}

This paper has shown that probiotics have been extensively used in order to prevent and treat inflammatory bowel diseases. The mechanism of action of these beneficial microbes, which includes changes in the gut microbiota, stimulation of the host immune responses, and reduction of the oxidative stress due to their antioxidant properties and antioxidant enzyme production has been demonstrated principally using animal models and in specific human trials. It has recently been suggested that there is a lack of welldesigned, large, randomized, placebo-controlled trials that can certify that probiotics are effective in the prevention and treatment of IBD [125]. Additional studies such as the double-blind, randomized, placebo-controlled clinical trial of the treatment of relapsing mild-to-moderate ulcerative colitis with the probiotic VSL\#3 as adjunctive to a standard pharmaceutical treatment [126] are required to confirm animal data and are necessary to convince the medical and general community of the benefits and potential application of probiotics in the prevention and treatment of IBD.

Although probiotic effects are a strain-dependent trait, using modern genetic engineering techniques it is theoretically possible to obtain strains that can exert a variety of beneficial properties. For example, the introduction of antioxidant enzyme genes in current probiotic strains that have natural antiinflammatory properties, such as the ability to modulate the immune-dependant inflammatory processes, could generate very useful strains that could be applied in the treatment of a variety of inflammatory diseases. These strains could also be included in treatment protocols since it has been shown that probiotics can enhance the effectiveness of traditional IBD treatments. However, before proposing the genetic modification of antiinflammatory strains, the innate mechanisms of the potential host strains should be demonstrated in properly designed largescale human clinical trials. These trials are essential in future studies using the engineered strains to demonstrate the differences between the native and modified strains.

The consumption of engineered strains by humans is still highly controversial due to the public perception that genetic manipulation is not "natural". Scientists must perform welldesign studies where the results are divulged to the general populations in order to inform consumers of the obvious beneficial effects these novel techniques can confer with the minimum of risk to their health and to the environment. Throughout the course of history, most novel treatments have met resistance from potential benefactors, it is thus important to show that the potential benefits are highly superior than the risks for novel treatments to be completely accepted by the population as a whole.

\section{Acknowledgments}

The authors would like to thank the Consejo Nacional de Investigaciones Científicas y Técnicas (CONICET), Agencia Nacional de Promoción Científica y Tecnológica (ANPCyT), Consejo de Investigaciones de la Universidad Nacional de Tucumán (CIUNT), the Centro Argentino Brasileño de Biotecnología (CABBIO), the Coordenação de Aperfeiçoamento de Pessoal de Nível Superior (CAPES), Fundação de Amparo à Pesquisa do Estado de Minas Gerais (FAPEMIG), and the Conselho Nacional de 
Desenvolvimento Científico e Tecnológico (CNPq) for their financial support.

\section{References}

[1] K. A. Head and J. S. Jurenka, "Inflammatory bowel disease part I: ulcerative colitis-pathophysiology and conventional and alternative treatment options," Alternative Medicine Review, vol. 8, no. 3, pp. 247-283, 2003.

[2] D. C. Baumgart and W. J. Sandborn, "Inflammatory bowel disease: clinical aspects and established and evolving therapies," The Lancet, vol. 369, no. 9573, pp. 1641-1657, 2007.

[3] A. B. Price, "Inflammatory bowel disease," in Oxford Textbook of Pathology, J. O. D. McGee, P. G. Isaacson, and N. A. Wright, Eds., Oxford University Press, Oxford, UK, 1992.

[4] C. O. Elson and C. T. Weaver, "Experimental mouse models of inflammatory bowel disease: new insights into pathogenic mechanisms," in Inflammatory Bowel Disease. From Bench to Bedside, S. R. Targan, F. Shanahan, and L. C. Karp, Eds., pp. 1-4, Springer Science+Business Media, New York, NY, USA, 2003.

[5] A. R. Jurjus, N. N. Khoury, and J. M. Reimund, "Animal models of inflammatory bowel disease," Journal of Pharmacological and Toxicological Methods, vol. 50, no. 2, pp. 81-92, 2004.

[6] E. Furrie, S. Macfarlane, A. Kennedy et al., "Synbiotic therapy (Bifidobacterium longum/Synergy 1) initiates resolution of inflammation in patients with active ulcerative colitis: a randomised controlled pilot trial," Gut, vol. 54, no. 2, pp. 242-249, 2005.

[7] H. H. Cui, C. L. Chen, J. D. Wang et al., "Effects of probiotic on intestinal mucosa of patients with ulcerative colitis," World Journal of Gastroenterology, vol. 10, no. 10, pp. 15211525, 2004.

[8] I. M. Carroll, J. M. Andrus, J. M. Bruno-Bárcena, T. R. Klaenhammer, H. M. Hassan, and D. S. Threadgill, "Antiinflammatory properties of Lactobacillus gasseri expressing manganese superoxide dismutase using the interleukin 10deficient mouse model of colitis," American Journal of Physiology, vol. 293, no. 4, pp. G729-G738, 2007.

[9] L. Peran, S. Sierra, M. Comalada et al., "A comparative study of the preventative effects exerted by two probiotics, Lactobacillus reuteri and Lactobacillus fermentum, in the trinitrobenzenesulfonic acid model of rat colitis," British Journal of Nutrition, vol. 97, no. 1, pp. 96-103, 2007.

[10] S. Matsumoto, T. Hara, T. Hori et al., "Probiotic Lactobacillus-induced improvement in murine chronic inflammatory bowel disease is associated with the downregulation of pro-inflammatory cytokines in lamina propria mononuclear cells," Clinical and Experimental Immunology, vol. 140, no. 3, pp. 417-426, 2005.

[11] M. Carol, N. Borruel, M. Antolin et al., "Modulation of apoptosis in intestinal lymphocytes by a probiotic bacteria in Crohn's disease," Journal of Leukocyte Biology, vol. 79, no. 5, pp. 917-922, 2006.

[12] M. Schultz, C. Veltkamp, L. A. Dieleman et al., "Lactobacillus plantarum $299 \mathrm{~V}$ in the treatment and prevention of spontaneous colitis in interleukin-10-deficient mice," Inflammatory Bowel Diseases, vol. 8, no. 2, pp. 71-80, 2002.

[13] J. A. Peña and J. Versalovic, "Lactobacillus rhamnosus GG decreases TNF- $\alpha$ production in lipopolysaccharide-activated murine macrophages by a contact-independent mechanism," Cellular Microbiology, vol. 5, no. 4, pp. 277-285, 2003.
[14] H. Majamaa and E. Isolauri, "Probiotics: a novel approach in the management of food allergy," Journal of Allergy and Clinical Immunology, vol. 99, no. 2, pp. 179-185, 1997.

[15] B. Sheil, J. McCarthy, L. O’Mahony et al., "Is the mucosal route of administration essential for probiotic function? Subcutaneous administration is associated with attenuation of murine colitis and arthritis," Gut, vol. 53, no. 5, pp. 694700, 2004.

[16] L. O’Mahony, M. Feeney, S. O’Halloran et al., "Probiotic impact on microbial flora, inflammation and tumour development in IL-10 knockout mice," Alimentary Pharmacology and Therapeutics, vol. 15, no. 8, pp. 1219-1225, 2001.

[17] S. Flynn, D. van Sinderen, G. M. Thornton, H. Holo, I. F. Nes, and J. K. Collins, "Characterization of the genetic locus responsible for the production of ABP-118, a novel bacteriocin produced by the probiotic bacterium Lactobacillus salivarius subsp. salivarius UCC118," Microbiology, vol. 148, no. 4, pp. 973-984, 2002.

[18] K. L. Madsen, J. S. Doyle, L. D. Jewell, M. M. Tavernini, and R. N. Fedorak, "Lactobacillus species prevents colitis in interleukin 10 gene-deficient mice," Gastroenterology, vol. 116, no. 5, pp. 1107-1114, 1999.

[19] P. Gionchetti, F. Rizzello, U. Helwig et al., "Prophylaxis of pouchitis onset with probiotic therapy: a double-blind, placebo-controlled trial," Gastroenterology, vol. 124, no. 5, pp. 1202-1209, 2003.

[20] A. Venturi, P. Gionchetti, F. Rizzello et al., "Impact on the composition of the faecal flora by a new probiotic preparation: preliminary data on maintenance treatment of patients with ulcerative colitis," Alimentary Pharmacology and Therapeutics, vol. 13, no. 8, pp. 1103-1108, 1999.

[21] J. G. H. R. van Embden, W. R. Schouten, and L. M. C. Van Lieshout, "Pouchitis: result of microbial imbalance?" Gut, vol. 35, no. 5, pp. 658-664, 1994.

[22] P. Gionchetti, C. Amadini, F. Rizzello, A. Venturi, G. Poggioli, and M. Campieri, "Probiotics for the treatment of postoperativecomplications following intestinal surgery," Best Practice \& Research in Clinical Gastroenterology, vol. 17, no. 5, pp. 821-831, 2003.

[23] K. Kajander and R. Korpela, "Clinical studies on alleviating the symptoms of irritable bowel syndrome with a probiotic combination," Asia Pacific Journal of Clinical Nutrition, vol. 15, no. 4, pp. 576-580, 2006.

[24] N. Osman, D. Adawi, S. Ahrne, B. Jeppsson, and G. Molin, "Modulation of the effect of dextran sulfate sodium-induced acute colitis by the administration of different probiotic strains of Lactobacillus and Bifidobacterium," Digestive Diseases and Sciences, vol. 49, no. 2, pp. 320-327, 2004.

[25] P. Gupta, H. Andrew, B. S. Kirschner, and S. Guandalini, "Is Lactobacillus GG helpful in children with Crohn's disease? Results of a preliminary, open-label study," Journal of Pediatric Gastroenterology and Nutrition, vol. 31, no. 4, pp. 453-457, 2000.

[26] M. V. Herías, J. F. J. G. Koninkx, J. G. Vos, J. H. J. Huis in't Veld, and J. E. van Dijk, "Probiotic effects of Lactobacillus casei on DSS-induced ulcerative colitis in mice," International Journal of Food Microbiology, vol. 103, no. 2, pp. 143-155, 2005.

[27] H. C. Rath, K. H. Wilson, and R. B. Sartor, "Differential induction of colitis and gastritis in HLA-B27 transgenic rats selectively colonized with Bacteroides vulgatus or Escherichia coli," Infection and Immunity, vol. 67, no. 6, pp. 2969-2974, 1999. 
[28] E. F. Verdù, P. Bercik, B. Cukrowska et al., "Oral administration of antigens from intestinal flora anaerobic bacteria reduces the severity of experimental acute colitis in BALB/c mice," Clinical and Experimental Immunology, vol. 120, no. 1, pp. 46-50, 2000.

[29] P. Chandran, S. Satthaporn, A. Robins, and O. Eremin, "Inflammatory bowel disease: dysfunction of GALT and gut bacterial flora (I)," Surgeon, vol. 1, no. 2, pp. 63-75, 2003.

[30] S. Videla, J. Vilaseca, F. Guarner et al., "Role of intestinal microflora in chronic inflammation and ulceration of the rat colon," Gut, vol. 35, no. 8, pp. 1090-1097, 1994.

[31] C. Favier, C. Neut, C. Mizon, A. Cortot, J. F. Colombel, and J. Mizon, "Fecal $\beta$-D-galactosidase production and Bifidobacteria are decreased in Crohn's disease," Digestive Diseases and Sciences, vol. 42, no. 4, pp. 817-822, 1997.

[32] P. Seksik, L. Rigottier-Gois, G. Gramet et al., "Alterations of the dominant faecal bacterial groups in patients with Crohn's disease of the colon," Gut, vol. 52, no. 2, pp. 237-242, 2003.

[33] A. Swidsinski, A. Ladhoff, A. Pernthaler et al., "Mucosal flora in inflammatory bowel disease," Gastroenterology, vol. 122, no. 1, pp. 44-54, 2002.

[34] C. Schultsz, F. M. van den Berg, F. Ten Kate, G. N. J. Tytgat, and J. Dankert, "The intestinal mucus layer from patients with inflammatory bowel disease harbors high numbers of bacteria compared with controls," Gastroenterology, vol. 117, no. 5, pp. 1089-1097, 1999.

[35] S. J. Ott, M. Musfeldt, D. F. Wenderoth et al., "Reduction in diversity of the colonic mucosa associated bacterial microflora in patients with active inflammatory bowel disease," Gut, vol. 53, no. 5, pp. 685-693, 2004.

[36] M. P. Conte, S. Schippa, I. Zamboni et al., "Gut-associated bacterial microbiota in paediatric patients with inflammatory bowel disease," Gut, vol. 55, no. 12, pp. 1760-1767, 2006.

[37] M. Mylonaki, N. B. Rayment, D. S. Rampton, B. N. Hudspith, and J. Brostoff, "Molecular characterization of rectal mucosaassociated bacterial flora in inflammatory bowel disease," Inflammatory Bowel Diseases, vol. 11, no. 5, pp. 481-487, 2005.

[38] C. Vanderpool, F. Yan, and D. B. Polk, "Mechanisms of probiotic action: implications for therapeutic applications in inflammatory bowel diseases," Inflammatory Bowel Diseases, vol. 14, no. 11, pp. 1585-1596, 2008.

[39] D. Garrido, A. Suau, P. Pochart, S. Cruchet, and M. Gotteland, "Modulation of the fecal microbiota by the intake of a Lactobacillus johnsonii La1-containing product in human volunteers," FEMS Microbiology Letters, vol. 248, no. 2, pp. 249-256, 2005.

[40] J. G. LeBlanc, A. de Moreno de Leblanc, G. Perdigón et al., "Anti-inflammatory properties of lactic acid bacteria: current knowledge, applications and prospects," Anti-Infective Agents in Medicinal Chemistry, vol. 7, no. 3, pp. 148-154, 2008.

[41] FAO/WHO, "Report of a joint FAO/WHO expert consultation on evaluation of health and nutritional properties of probiotics in food including powder milk with live lactic acid bacteria," 2001.

[42] P. Marteau, P. Lepage, I. Mangin et al., "Gut flora and inflammatory bowel disease," Alimentary Pharmacology and Therapeutics, vol. 20, no. 4, pp. 18-23, 2004.

[43] C. P. Tamboli, C. Caucheteux, A. Cortot, J. F. Colombel, and P. Desreumaux, "Probiotics in inflammatory bowel disease: a critical review," Best Practice \& Research in Clinical Gastroenterology, vol. 17, no. 5, pp. 805-820, 2003.
[44] M. Guslandi, G. Mezzi, M. Sorghi, and P. A. Testoni, "Saccharomyces boulardii in maintenance treatment of Crohn's disease," Digestive Diseases and Sciences, vol. 45, no. 7, pp. 1462-1464, 2000.

[45] M. Malin, H. Suomalainen, M. Saxelin, and E. Isolauri, "Promotion of IgA immune response in patients with Crohn's disease by oral bacteriotherapy with Lactobacillus GG," Annals of Nutrition and Metabolism, vol. 40, no. 3, pp. 137-145, 1996.

[46] L. O'Mahony, J. Mccarthy, P. Kelly et al., "Lactobacillus and Bifidobacterium in irritable bowel syndrome: symptom responses and relationship to cytokine profiles," Gastroenterology, vol. 128, no. 3, pp. 541-551, 2005.

[47] A. C. Bittner, R. M. Croffut, M. C. Stranahan, and T. N. Yokelson, "Prescript-assist probiotic-prebiotic treatment for irritable bowel syndrome: an open-label, partially controlled, 1 -year extension of a previously published controlled clinical trial," Clinical Therapeutics, vol. 29, no. 6, pp. 1153-1160, 2007.

[48] A. C. Bittner, R. M. Croffut, and M. C. Stranahan, "Prescriptassist probiotic-prebiotic treatment for irritable bowel syndrome: a methodologically oriented, 2-week, randomized, placebo-controlled, double-blind clinical study," Clinical Therapeutics, vol. 27, no. 6, pp. 755-761, 2005.

[49] T. Mimura, F. Rizzello, U. Helwig et al., "Once daily high dose probiotic therapy (VSL\#3) for maintaining remission in recurrent or refractory pouchitis," Gut, vol. 53, no. 1, pp. 108-114, 2004.

[50] W. Kruis, P. Frič, J. Pokrotnieks et al., "Maintaining remission of ulcerative colitis with the probiotic Escherichia coli Nissle 1917 is as effective as with standard mesalazine," Gut, vol. 53, no. 11, pp. 1617-1623, 2004.

[51] A. Tursi, G. Brandimarte, G. M. Giorgetti, G. Forti, M. E. Modeo, and A. Gigliobianco, "Low-dose balsalazide plus a high-potency probiotic preparation is more effective than balsalazide alone or mesalazine in the treatment of acute mild-to-moderate ulcerative colitis," Medical Science Monitor, vol. 10, no. 11, pp. PI126-PI131, 2004.

[52] O. Karimi, A. S. Peña, and A. A. van Bodegraven, "Probiotics (VSL\#3) in arthralgia in patients with ulcerative colitis and Crohn's disease: a pilot study," Drugs of Today, vol. 41, no. 7, pp. 453-459, 2005.

[53] E. Isolauri, S. Salminen, and A. C. Ouwehand, "Microbial-gut interactions in health and disease. Probiotics," Best Practice \& Research Clinical Gastroenterology, vol. 18, pp. 299-313, 2004.

[54] T. R. Klaenhammer, "Bacteriocins of lactic acid bacteria," Biochimie, vol. 70, no. 3, pp. 337-349, 1988.

[55] M. C. Rea, E. Clayton, P. M. O’Connor et al., “Antimicrobial activity of lacticin 3147 against clinical Clostridium difficile strains," Journal of Medical Microbiology, vol. 56, no. 7, pp. 940-946, 2007.

[56] M. Schultz, K. Munro, G. W. Tannock et al., "Effects of feeding a probiotic preparation (SIM) containing inulin on the severity of colitis and on the composition of the intestinal microflora in HLA-B27 transgenic rats," Clinical and Diagnostic Laboratory Immunology, vol. 11, no. 3, pp. 581-587, 2004.

[57] M. Campieri, F. Rizzello, A. Venturi et al., "Combination of antibiotic and probiotic treatment is efficacious in prophylaxis of post-operative recurrence of Crohn's disease: a randomised controlled study v. mesalazine," Gastroenterology, vol. 118, p. A4179, 2000. 
[58] P. Gionchetti, F. Rizzello, A. Venturi et al., "Oral bacteriotherapy as maintenance treatment in patients with chronic pouchitis: a double-blind, placebo-controlled trial," Gastroenterology, vol. 119, no. 2, pp. 305-309, 2000.

[59] M. J. Ruddy, G. C. Wong, X. K. Liu et al., "Functional cooperation between interleukin-17 and tumor necrosis factor- $\alpha$ is mediated by CCAAT/enhancer-binding protein family members," Journal of Biological Chemistry, vol. 279, no. 4, pp. 2559-2567, 2004.

[60] F. Leon, L. E. Smythies, P. D. Smith, and B. L. Kelsall, "Involvement of dendritic cells in the pathogenesis of inflammatory bowel disease," Advances in Experimental Medicine and Biology, vol. 579, pp. 117-132, 2006.

[61] D. K. Podolsky, "Inflammatory bowel disease," The New England Journal of Medicine, vol. 347, no. 6, pp. 417-429, 2002.

[62] S. Brand, “Crohn's disease: Th1, Th17 or both? The change of a paradigm: new immunological and genetic insights implicate Th17 cells in the pathogenesis of Crohn's disease," Gut, vol. 58, no. 8, pp. 1152-1167, 2009.

[63] M. F. Neurath, I. Fuss, B. L. Kelsall, D. H. Presky, W. Waegell, and W. Strober, "Experimental granulomatous colitis in mice is abrogated by induction of TGF- $\beta$-mediated oral tolerance," Journal of Experimental Medicine, vol. 183, no. 6, pp. 26052616, 1996.

[64] H. Jonuleit, E. Schmitt, M. Stassen, A. Tuettenberg, J. Knop, and A. H. Enk, "Identification and functional characterization of human $\mathrm{CD} 4{ }^{+} \mathrm{CD} 25^{+} \mathrm{T}$ cells with regulatory properties isolated from peripheral blood," Journal of Experimental Medicine, vol. 193, no. 11, pp. 1285-1294, 2001.

[65] Y. Cong, C. T. Weaver, A. Lazenby, and C. O. Elson, "Bacterial-reactive $\mathrm{T}$ regulatory cells inhibit pathogenic immune responses to the enteric flora," Journal of Immunology, vol. 169, no. 11, pp. 6112-6119, 2002.

[66] A. Kappeler and C. Mueller, "The role of activated cytotoxic T cells in inflammatory bowel disease," Histology and Histopathology, vol. 15, no. 1, pp. 167-172, 2000.

[67] G. Perdigón, E. Vintiñi, S. Alvarez, M. Medina, and M. Medici, "Study of the possible mechanisms involved in the mucosal immune system activation by lactic acid bacteria," Journal of Dairy Science, vol. 82, no. 6, pp. 1108-1114, 1999.

[68] G. Perdigon, M. Medina, E. Vintini, and J. C. Valdez, "Intestinal pathway of internalisation of lactic acid bacteria and gut mucosal immunostimulation," International Journal of Immunopathology and Pharmacology, vol. 13, no. 3, pp. 141-150, 2000.

[69] T. Pessi, Y. Sütas, M. Hurme, and E. Isolauri, "Interleukin10 generation in atopic children following oral lactobacillus rhamnosus GG," Clinical and Experimental Allergy, vol. 30, no. 12, pp. 1804-1808, 2000.

[70] A. de Moreno de Leblanc, S. Chaves, and G. Perdigón, "Effect of yoghurt on the cytokine profile using a murine model of intestinal inflammation," European Journal of Inflammation, vol. 7, no. 2, pp. 97-109, 2009.

[71] A. P. Bai, Q. Ouyang, X. R. Xiao, and S. F. Li, "Probiotics modulate inflammatory cytokine secretion from inflamed mucosa in active ulcerative colitis," International Journal of Clinical Practice, vol. 60, no. 3, pp. 284-288, 2006.

[72] C. O. Elson, "From cheese to pharma: a designer probiotic for IBD," Clinical Gastroenterology and Hepatology, vol. 4, no. 7, pp. 836-837, 2006.
[73] K. Ina, J. Itoh, K. Fukushima et al., "Resistance of Crohn's disease T cells to multiple apoptotic signals is associated with a Bcl-2/Bax mucosal imbalance," Journal of Immunology, vol. 163, no. 2, pp. 1081-1090, 1999.

[74] J. Itoh, C. de la Motte, S. A. Strong, A. D. Levine, and C. Fiocchi, "Decreased Bax expression by mucosal T cells favours resistance to apoptosis in Crohn's disease," Gut, vol. 49, no. 1, pp. 35-41, 2001.

[75] R. Atreya, J. Mudter, S. Finotto et al., "Erratum: Blockade of interleukin 6 trans signaling suppresses T-cell resistance against apoptosis in chronic intestinal inflammation: evidence in Crohn disease and experimental colitis in vivo," Nature Medicine, vol. 16, no. 11, p. 1341, 2010.

[76] G. Friedman and J. T. George, "Treatment of refractory 'pouchitis' with prebiotic and probiotic therapy," Gastroenterology, vol. 118, p. A4167, 2000.

[77] W. Kruis, E. Schütz, P. Fric, B. Fixa, G. Judmaier, and M. Stolte, "Double-blind comparison of an oral Escherichia coli preparation and mesalazine in maintaining remission of ulcerative colitis," Alimentary Pharmacology and Therapeutics, vol. 11, no. 5, pp. 853-858, 1997.

[78] B. J. Rembacken, A. M. Snelling, P. M. Hawkey, D. M. Chalmers, and A. T. R. Axon, "Non-pathogenic Escherichia coli versus mesalazine for the treatment of ulcerative colitis: a randomised trial," The Lancet, vol. 354, no. 9179, pp. 635639, 1999.

[79] R. Kuhn, J. Lohler, D. Rennick, K. Rajewsky, and W. Muller, "Interleukin-10-deficient mice develop chronic enterocolitis," Cell, vol. 75, no. 2, pp. 263-274, 1993.

[80] H. Tilg, C. Van Montfrans, A. Van den Ende et al., "Treatment of Crohn's disease with recombinant human interleukin 10 induces the proinflammatory cytokine interferon $\gamma$," Gut, vol. 50, no. 2, pp. 191-195, 2002.

[81] H. H. Uhlig, J. Coombes, C. Mottet et al., "Characterization of Foxp $3^{+} \mathrm{CD} 4{ }^{+} \mathrm{CD} 25^{+}$and IL-10-secreting CD ${ }^{+} \mathrm{CD} 25^{+} \mathrm{T}$ cells during cure of colitis," Journal of Immunology, vol. 177, no. 9, pp. 5852-5860, 2006.

[82] M. Roselli, A. Finamore, S. Nuccitelli et al., "Prevention of TNBS-induced colitis by different Lactobacillus and Bifidobacterium strains is associated with an expansion of $\gamma \delta \mathrm{T}$ and regulatory $\mathrm{T}$ cells of intestinal intraepithelial lymphocytes," Inflammatory Bowel Diseases, vol. 15, no. 10, pp. 1526-1536, 2009.

[83] E. Mengheri, "Health, probiotics, and inflammation," Journal of clinical gastroenterology, vol. 42, pp. S177-S178, 2008.

[84] S. Ishihara, M. A. K. Rumi, C. F. Ortega-Cava et al., "Therapeutic targeting of toll-like receptors in gastrointestinal inflammation," Current Pharmaceutical Design, vol. 12, no. 32, pp. 4215-4228, 2006.

[85] P. Pimentel-Nunes, J. B. Soares, R. Roncon-Albuquerque, M. Dinis-Ribeiro, and A. F. Leite-Moreira, "Toll-like receptors as therapeutic targets in gastrointestinal diseases," Expert Opinion on Therapeutic Targets, vol. 14, no. 4, pp. 347-368, 2010.

[86] C. M. Galdeano, A. de Moreno de Leblanc, G. Vinderola, M. E. Bonet, and G. Perdigón, "Proposed model: mechanisms of immunomodulation induced by probiotic bacteria," Clinical and Vaccine Immunology, vol. 14, no. 5, pp. 485-492, 2007.

[87] C. M. Galdeano, A. de Moreno de Leblanc, E. Carmuega, R. Weill, and G. Perdigón, "Mechanisms involved in the immunostimulation by probiotic fermented milk," Journal of Dairy Research, vol. 76, no. 4, pp. 446-454, 2009. 
[88] M. G. Vizoso Pinto, M. Rodriguez Gómez, S. Seifert, B. Watzl, W. H. Holzapfel, and C. M. A. P. Franz, "Lactobacilli stimulate the innate immune response and modulate the TLR expression of HT29 intestinal epithelial cells in vitro," International Journal of Food Microbiology, vol. 133, no. 1-2, pp. 86-93, 2009.

[89] M. Schultz and A. L. Lindström, "Rationale for probiotic treatment strategies in inflammatory bowel disease," Expert Review of Gastroenterology and Hepatology, vol. 2, no. 3, pp. 337-355, 2008.

[90] M. Fukata and M. T. Abreu, "TLR4 signalling in the intestine in health and disease," Biochemical Society Transactions, vol. 35, no. 6, pp. 1473-1478, 2007.

[91] C. A. Dogi, C. M. Galdeano, and G. Perdigón, "Gut immune stimulation by non pathogenic $\mathrm{Gram}^{+}$and $\mathrm{Gram}^{-}$bacteria. Comparison with a probiotic strain," Cytokine, vol. 41, no. 3, pp. 223-231, 2008.

[92] Y. W. Chung, J. H. Choi, T. Y. Oh, C. S. Eun, and D. S. Han, "Lactobacillus casei prevents the development of dextran sulphate sodium-induced colitis in Toll-like receptor 4 mutant mice," Clinical and Experimental Immunology, vol. 151, no. 1, pp. 182-189, 2008.

[93] D. Rachmilewitz, F. Karmeli, K. Takabayashi et al., "Immunostimulatory DNA ameliorates experimental and spontaneous murine colitis," Gastroenterology, vol. 122, no. 5, pp. 1428-1441, 2002.

[94] F. Obermeier, N. Dunger, U. G. Strauch et al., "CpG motifs of bacterial DNA essentially contribute to the perpetuation of chronic intestinal inflammation," Gastroenterology, vol. 129, no. 3, pp. 913-927, 2005.

[95] M. Akhtar, J. L. Watson, A. Nazli, and D. M. McKay, "Bacterial DNA evokes epithelial IL-8 production by a MAPK-dependent, NF-kappaB-independent pathway," The FASEB Journal, vol. 17, no. 10, pp. 1319-1321, 2003.

[96] J. Lee, D. Rachmilewitz, and E. Raz, "Homeostatic effects of TLR9 signaling in experimental colitis," Annals of the New York Academy of Sciences, vol. 1072, pp. 351-355, 2006.

[97] D. Rachmilewitz, K. Katakura, F. Karmeli et al., "Toll-like receptor 9 signaling mediates the anti-inflammatory effects of probiotics in murine experimental colitis," Gastroenterology, vol. 126, no. 2, pp. 520-528, 2004.

[98] D. Rachmilewitz, F. Karmeli, S. Shteingart, J. Lee, K. Takabayashi, and E. Raz, "Immunostimulatory oligonucleotides inhibit colonic proinflammatory cytokine production in ulcerative colitis," Inflammatory Bowel Diseases, vol. 12, no. 5, pp. 339-345, 2006.

[99] N. Kamada, N. Inoue, T. Hisamatsu et al., "Nonpathogenic Escherichia coli strain Nissle 1917 prevents murine acute and chronic colitis," Inflammatory Bowel Diseases, vol. 11, no. 5, pp. $455-463,2005$.

[100] A. Miyoshi, L. Bermudez-Humaran, M. Pacheco de Azevedo, P. Langella, and V. Azevedo, "Lactic acid bacteria as live vectors: heterologous protein production and delivery systems," in Biotechnology of Lactic Acid Bacteria Novel Applications, F. Mozzi, R. Raya, and G. Vignolo, Eds., pp. 1-9, Blackwell Publishing, Ames, Iowa, USA, 2010.

[101] L. Steidler, W. Hans, L. Schotte et al., "Treatment of murine colitis by Lactococcus lactis secreting interleukin-10," Science, vol. 289, no. 5483, pp. 1352-1355, 2000.

[102] H. Braat, P. Rottiers, D. W. Hommes et al., "A phase I trial with transgenic bacteria expressing interleukin-10 in Crohn's disease," Clinical Gastroenterology and Hepatology, vol. 4, no. 6, pp. 754-759, 2006.
[103] F. A. V. Marinho, L. G. G. Pacífico, A. Miyoshi et al., "An intranasal administration of Lactococcus lactis strains expressing recombinant interleukin-10 modulates acute allergic airway inflammation in a murine model," Clinical and Experimental Allergy, vol. 40, no. 10, pp. 1541-1551, 2010.

[104] A. Keshavarzian, A. Banan, A. Farhadi et al., "Increases in free radicals and cytoskeletal protein oxidation and nitration in the colon of patients with inflammatory bowel disease," Gut, vol. 52, no. 5, pp. 720-728, 2003.

[105] L. Lih-Brody, S. R. Powell, K. P. Collier et al., "Increased oxidative stress and decreased antioxidant defenses in mucosa of inflammatory bowel disease," Digestive Diseases and Sciences, vol. 41, no. 10, pp. 2078-2086, 1996.

[106] S. Sedghi, J. Z. Fields, M. Klamut et al., "Increased production of luminol enhanced chemiluminescence by the inflamed colonic mucosa in patients with ulcerative colitis," Gut, vol. 34, no. 9, pp. 1191-1197, 1993.

[107] N. J. Simmonds, R. E. Allen, T. R. J. Stevens, R. N. M. Van Someren, D. R. Blake, and D. S. Rampton, "Chemiluminescence assay of mucosal reactive oxygen metabolites in inflammatory bowel disease," Gastroenterology, vol. 103, no. 1, pp. 186-196, 1992.

[108] S. Condon, "Responses of lactic acid bacteria to oxygen," FEMS Microbiology Letters, vol. 46, no. 3, pp. 269-280, 1987.

[109] D. Roos, "The involvement of oxygen radicals in microbicidal mechanisms of leukocytes and macrophages," Klinische Wochenschrift, vol. 69, no. 21-23, pp. 975-980, 1991.

[110] B. S. Berlett and E. R. Stadtman, "Protein oxidation in aging, disease, and oxidative stress," Journal of Biological Chemistry, vol. 272, no. 33, pp. 20313-20316, 1997.

[111] S. B. Farr and T. Kogoma, "Oxidative stress responses in Escherichia coli and Salmonella typhimurium," Microbiological Reviews, vol. 55, no. 4, pp. 561-585, 1991.

[112] T. P. Szatrowski and C. F. Nathan, "Production of large amounts of hydrogen peroxide by human tumor cells," Cancer Research, vol. 51, no. 3, pp. 794-798, 1991.

[113] L. Kruidenier and H. W. Verspaget, "Oxidative stress as a pathogenic factor in inflammatory bowel disease-radicals or ridiculous?" Alimentary Pharmacology and Therapeutics, vol. 16, no. 12, pp. 1997-2015, 2002.

[114] L. Kruidenier, M. E. van Meeteren, I. Kuiper et al., "Attenuated mild colonic inflammation and improved survival from severe DSS-colitis of transgenic Cu/Zn-SOD mice," Free Radical Biology and Medicine, vol. 34, no. 6, pp. 753-765, 2003.

[115] B. G. Spyropoulos, E. P. Misiakos, C. Fotiadis, and C. N. Stoidis, "Antioxidant properties of probiotics and their protective effects in the pathogenesis of radiationinduced enteritis and colitis," Digestive Diseases and Sciences. In press.

[116] C. Grangette, S. Nutten, E. Palumbo et al., "Enhanced antiinflammatory capacity of a Lactobacillus plantarum mutant synthesizing modified teichoic acids," Proceedings of the National Academy of Sciences of the United States of America, vol. 102, no. 29, pp. 10321-10326, 2005.

[117] T. Rochat, L. Bermúdez-Humarán, J. J. Gratadoux et al., "Anti-inflammatory effects of Lactobacillus casei BL23 producing or not a manganese-dependant catalase on DSSinduced colitis in mice," Microbial Cell Factories, vol. 6, article no. 22, 2007. 
[118] A. de Moreno de Leblanc, J. G. LeBlanc, G. Perdigón et al., "Oral administration of a catalase-producing Lactococcus lactis can prevent a chemically induced colon cancer in mice," Journal of Medical Microbiology, vol. 57, no. 1, pp. 100-105, 2008.

[119] W. Han, A. Mercenier, A. Ait-Belgnaoui et al., "Improvement of an experimental colitis in rats by lactic acid bacteria producing superoxide dismutase," Inflammatory Bowel Diseases, vol. 12, no. 11, pp. 1044-1052, 2006.

[120] L. Watterlot, T. Rochat, H. Sokol et al., "Intragastric administration of a superoxide dismutase-producing recombinant Lactobacillus casei BL23 strain attenuates DSS colitis in mice," International Journal of Food Microbiology, vol. 144, no. 1, pp. 35-41, 2010.

[121] J. G. LeBlanc, S. del Carmen, A. Miyoshi et al., "Use of superoxide dismutase and catalase expressing lactic acid bacteria to attenuate TNBS induced Crohn's disease in mice," Journal of Biotechnology. In press.

[122] L. Watterlot, T. Rochat, H. Sokol et al., "Intragastric administration of a superoxide dismutase-producing recombinant Lactobacillus casei BL23 strain attenuates DSS colitis in mice," International Journal of Food Microbiology, vol. 144, pp. 35-41, 2010.

[123] T. Rochat, A. Miyoshi, J. J. Gratadoux et al., "High-level resistance to oxidative stress in Lactococcus lactis conferred by Bacillus subtilis catalase KatE," Microbiology, vol. 151, no. 9, pp. 3011-3018, 2005.

[124] T. Rochat, J. J. Gratadoux, A. Gruss et al., "Production of a heterologous nonheme catalase by Lactobacillus casei: an efficient tool for removal of $\mathrm{H}_{2} \mathrm{O}_{2}$ and protection of Lactobacillus bulgaricus from oxidative stress in milk," Applied and Environmental Microbiology, vol. 72, no. 8, pp. 5143-5149, 2006.

[125] P. Mallon, D. McKay, S. Kirk, and K. Gardiner, "Probiotics for induction of remission in ulcerative colitis," Cochrane Database of Systematic Reviews, no. 4, Article ID CD005573, 2007.

[126] A. Tursi, G. Brandimarte, A. Papa et al., "Treatment of relapsing mild-to-moderate ulcerative colitis with the probiotic VSL\#3 as adjunctive to a standard pharmaceutical treatment: a double-blind, randomized, placebo-controlled study," American Journal of Gastroenterology, vol. 105, no. 10, pp. 2218-2227, 2010. 


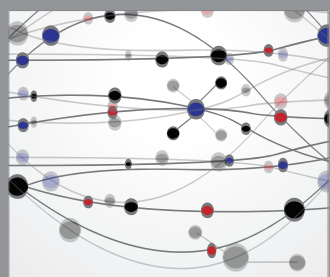

The Scientific World Journal
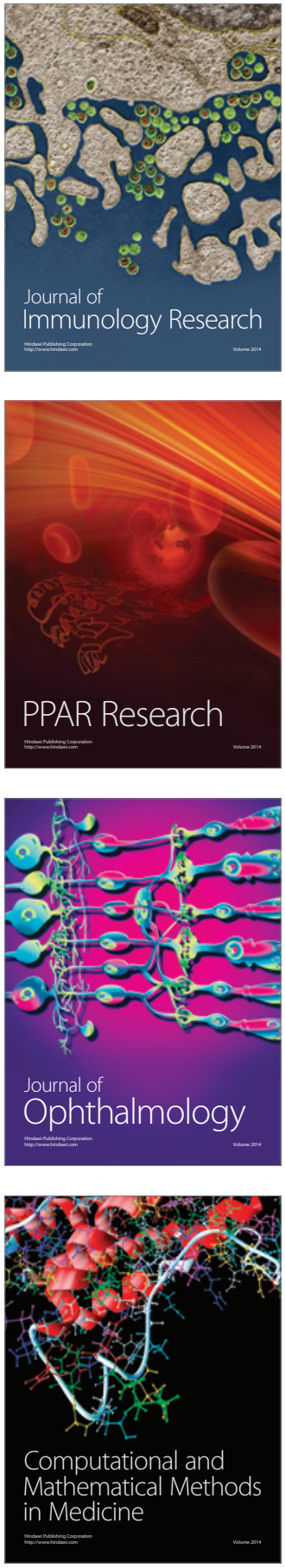

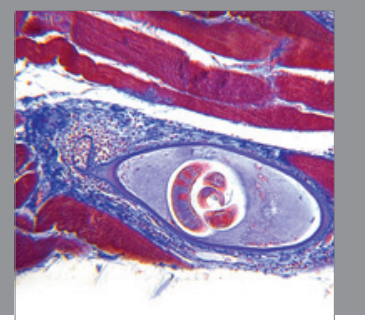

Gastroenterology

Research and Practice
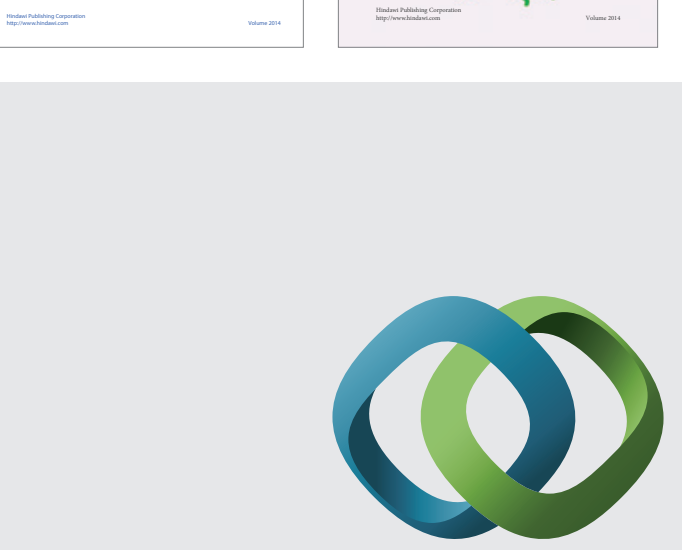

\section{Hindawi}

Submit your manuscripts at

http://www.hindawi.com
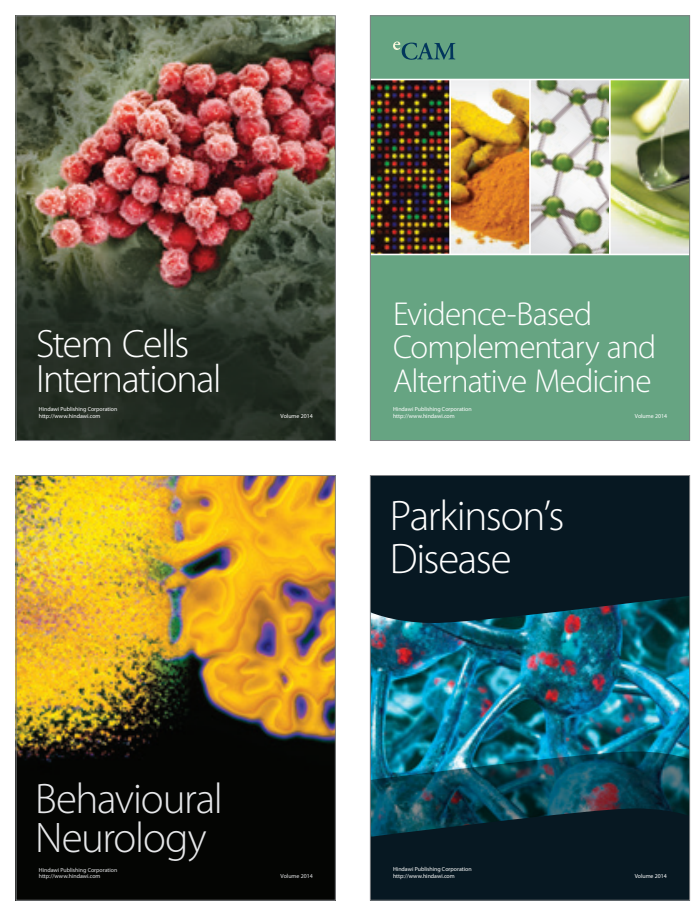

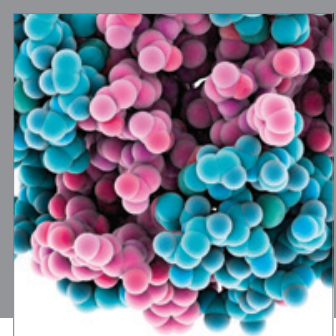

Journal of
Diabetes Research

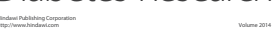

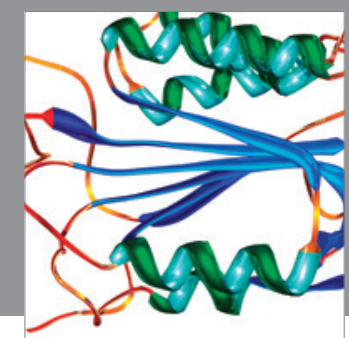

Disease Markers
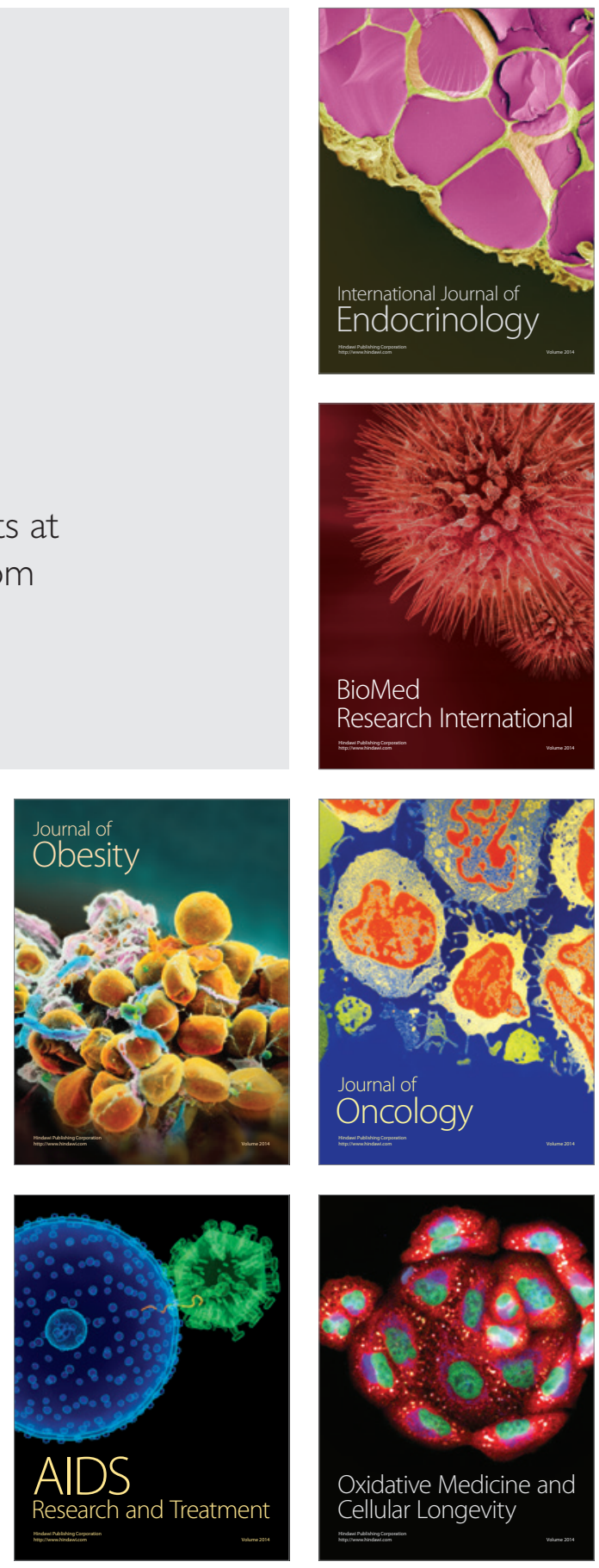